\title{
Potential Effects of Environmental Change on Mining Wastes in a Hyperarid Climate
}

\author{
Douglas B. Sims ${ }^{1,2}$, Peter S. Hooda ${ }^{2} \&$ Gavin K. Gillmore ${ }^{2}$ \\ ${ }^{1}$ Sims \& Associates, LLC, Western Region, 10816 Marandola Street, Las Vegas, USA \\ ${ }^{2}$ Kingston University London, Penrhyn Road, Kingston upon Thames, UK \\ Correspondence: Douglas B. Sims, Sims \& Associates, LLC, Western Region, 10816 Marandola Street, Las \\ Vegas, NV 89141, USA. Tel: 1-512-809-5094. E-mail: doug@simsassociates.net
}

Received: February 22, 2012 Accepted: March 23, 2012 Online Published: June 14, 2012

doi:10.5539/ep.v1n2p61

URL: http://dx.doi.org/10.5539/ep.v1n2p61

\begin{abstract}
Three desert washes were sampled to evaluate the transport of contaminated sediments from abandoned mining sites to downwash environments. The area of concern is an extreme arid climate considered stable and not to pose pathways for contaminated sediments to impact downwash environments. Research of mine wastes in Nelson, Nevada has shown that residual geogenic and anthropogenic trace elements have been mobilized in surface sediments as a result of storm event. Cyanide and trace elements, especially mercury and lead, have transported to $6000 \mathrm{~m}$ downwash from source areas. Short term environmental impacts appear to be minimal because of present-day environmental conditions. However, climate shifts caused by the El Nino Southern Oscillations or even a dramatic climate shift might increase regional precipitation promoting a more rapid erosion of contaminated sediment. Currently, wash sediments do not contain levels of $\mathrm{CN}^{-}$or trace elements that pose threats to the environment; however, if erosion and transport of mining waste increased because of additional precipitation, then $\mathrm{CN}^{-}$and trace elements loading in storm water would increase, with their possibly delivery to Lake Mohave.
\end{abstract}

Keywords: Mining, trace metals, Nevada, climate Change, sediments

\section{Introduction}

Precious metals exploration in the American West has been an important factor in the development of the United States west of the Mississippi River (Sims, 2011). Mining activities have occurred in temperate and semi-arid climates as well as in the Mojave Desert, an arid region in the south-western United States (Hughes \& Diaz, 2008). Most research on environmental impacts of mining in arid climate has focused on aeolian dispersion of tailings and milling wastes (Meza-Figueroa et al., 2009). Wind can have a major impact on the transport and distribution of trace element-laden dust originating from mine tailings in semi-arid or arid climates (Meza-Figueroa et al., 2009; Hayes et al., 2009). In humid and temperate areas where runoff transports contaminants as both dissolved and suspended particulate phases beyond source areas, ecological and human health risks can be substantial (e.g. Slowey et al., 2007; Jamieson et al., 2004; Alvarez-Ayuso et al., 2008). However, such environmental risks are considered much less in areas where low precipitation, e.g., hyperarid regions of the American Southwest, limits the transport and exposure of mine waste contaminants to the wider environment (Navarro et al., 2008; Hayes et al., 2009).

Unlike temperate or non-dry climates, abandoned mining sites in hyperarid environments have not received much attention in terms of assessing environmental threats they pose or the potential for increased risk, possibly mediated by climate change (Hughes \& Diaz, 2008; Sims, 2010). In the Mojave Desert, climate is relatively stable and predictable however, global climate conditions can foment change to terrestrial environments from temporary environmental shifts such as the El Nino Southern Oscillations (ENSO) or more dramatic shifts caused by climate change (Holmgren et al., 2001; Dillon \& Rundel, 1990; Rodriguez et al., 2005).

Studies in the Mojave Desert have shown a 4\% increase in the frequency of heavy rainfall events during the latter part of the $20^{\text {th }}$ century further indicating the possibility of change in arid regions such as Nelson, Nevada (Dore, 2005; Serrat-Capdevila, 2007), perhaps developing more significant environmental impacts than presently exist. Despite current conditions, some authors suggest climate change will impact the Mojave Desert with 
probable increases in precipitation, creating conditions favorable for greater mobility of contaminants (Hereford et al., 2006; Gillespie \& Loik, 2004).

Localized weather events for Nelson and the surrounding area only started in 2008 when the National Weather Service installed station in Searchlight, Nevada, 17 miles south of Nelson (NWS, 2011). Since its installation, the area has been in a major drought cycle with a total precipitation of $<7 \mathrm{~mm}$ of rainfall between January 2008 and December 2010, a significantly lower amount than the expected annual average of $7 \mathrm{~cm}$ (BOR, 1995). The average event during this period (2008-10) produced $<0.5 \mathrm{~mm}$ resulting in little or no overland flow. Because of the lack of recorded events in recent years, and the localized nature of storms across this region, data were mined from newspapers of the Las Vegas Review Journal for stories pertaining to storm events that occurred in the Nelson area. It was observed that localized storm events produce significant rainfall $>2 \mathrm{~cm}$ in a short period of time (20 minutes) in Southern Nevada and Nelson area.

Recent studies on climate change predictive models have considered whether climate can affect environmental conditions with further desertification, steady state conditions, or increased precipitation (Giannini et al., 2008; Giorgi \& Lionello, 2008; Hancock, 2009). Understanding the potential effects of climate change in regions where current conditions indicate a stable, low impact environment is imperative when considering pathways for abandoned mine waste to impact a wider area.

In this field study, we investigated mine tailings and milling wastes in dry wash sediments to assess the current risks posed to downgradient environments in a hyperarid region. Three wash systems (Carnation, Eagle and Techatticup washes) near Nelson were chosen to evaluate the levels of contaminants $\left(\mathrm{CN}^{-}, \mathrm{Hg}\right.$, and $\left.\mathrm{Pb}\right)$ in the mine waste and their possible mobilization downwash (Figure 1) with occasional storm runoff events, as well how the current situation may be influenced by climate change. This study used precipitation records along with the Universal Soil Loss Equation to make broad predictions on the wider environment, mainly, sub regional areas like downwash areas of Nelson, NV. Objectives were to determine if existing conditions pose any environmental risks to downwash areas. Furthermore, if plausible, will future short term (e.g ENSO) or long term changes (e.g. climate change) increase risk to downwash areas.

\section{Materials and Methods}

\subsection{Study Area}

Mining areas near Nelson, Nevada contains ore bodies composed of quartz monzonite dikes with Precambrian deposits of garnetiferous granite gneiss, and Tertiary, and Quaternary units (Hansen, 1962; Longwell et al., 1965) Quaternary age materials typically consist of fluvial and alluvial unconsolidated sediments. Average elevation where the sampling was performed range from $944.9 \mathrm{~m}$ above sea level (ASL) at the Town of Nelson to $137.2 \mathrm{~m}$ ASL along the Colorado River. Slope in the area is between 6-7\% from mountains to the Colorado River.

This area is considered part of the Mojave Desert and receives $<7 \mathrm{~cm}$ of precipitation annually (USDA-SCS, 1977). Though the area receives little rainfall, precipitation during the El Nino Southern Oscillation (ENCO) has been reported to increase 5 to 8 times the normal average (Holmgren et al., 2001; Rodriguez et al., 2005). The 'rainy season' is typically during the months of July and October, when roughly 35 to $40 \%$ of the measurable precipitation occurs in $1.5 \mathrm{~cm}$, or greater, events from a single summer thunderstorm (BOR, 1995). The nearest permanent water to Nelson is Lake Mojave, approximately $10 \mathrm{~km}$ downwash from source mines in the study area (Figure 1).

Data concerning precipitation in the study area is sparse before 2008 due to its remote location. However, there have been three historical storm events reported in local newspapers going back to 1957 (LVRJ, 2011). The first event reported was August 22, 1957 where a storm produced $6.5 \mathrm{~cm}$ of precipitation; a second on June 21, 1958 that produced $3.9 \mathrm{~cm}$ of precipitation; and finally on September 14, 1974, a storm produced $2.6 \mathrm{~cm}$ of precipitation. Data from 2008 onwards is available however, due to an on-going drought, the June 21, 1958 storm event measuring $3.9 \mathrm{~cm}$ can be considered a typical event that occurs in Southern Nevada, according to Greene (1975).

The sites investigated in this study are situated at the upper end of each wash where mines operated between the late 1800 s through the 1940s. These mines have since been abandoned with tailing enriched with trace elements are exposed to the environment. According to Longwell et al. (1965), operations at the Carnation mine/mill site, also called the Wall Street mine, processed approximately 35,869 metric tons of ore on site between 1938 and 1943; Eagle wash operations processed 53,456 metric tons through the 1940s; and approximately 250,000 metric tons of ore between 1860 and 1942 was processed at the Techatticup. The Carnation and Eagle mine sites contain waste piles situated on about 10 acres of land, whereas the Techatticup mine waste pile is situated on about 50 
acres (Longwell et al., 1965). Although enriched wastes have eroded into each of the three washes, environmental conditions today permit relatively small amounts of contaminated tailings transportation downwash. However, past storm runoff events may have transported mine tailings downwash, and it is also possible that an increase in precipitation could further mobilize and transport mine tailings from the source areas.

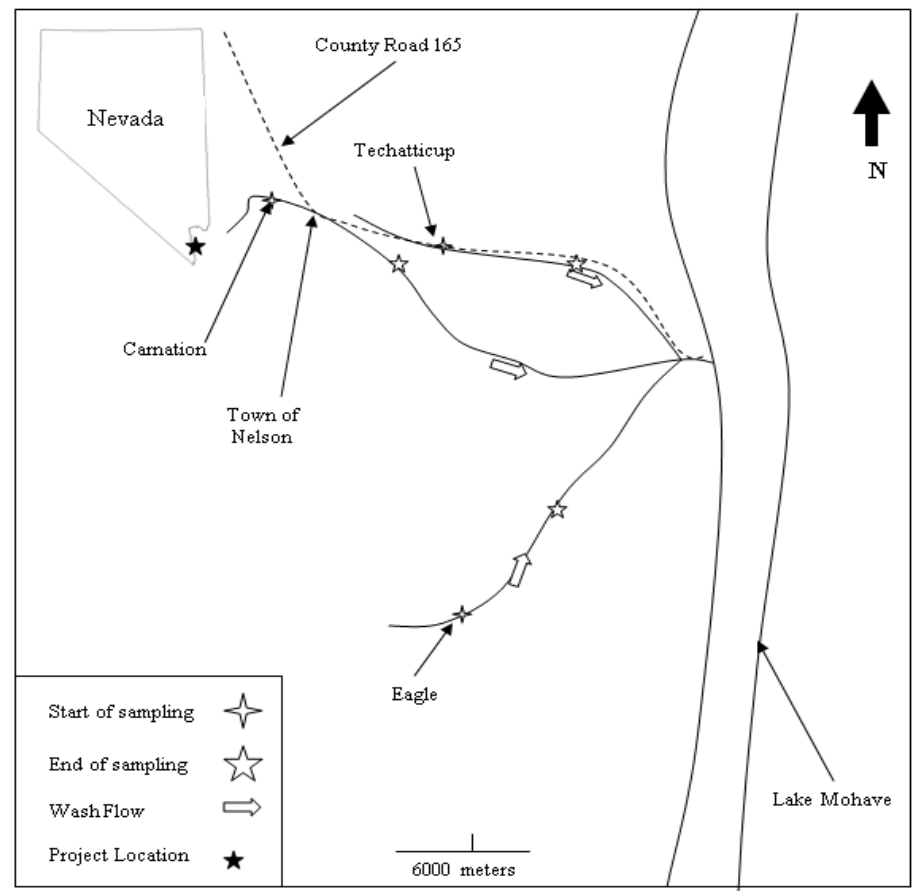

Figure 1. Sediment sampling start and finish in wash systems in relation to Lake Mohave, Nevada. Sampling start and end points are depicted on figure. Background sample points are where the sampling transects start

\subsection{Application of Universal Soil Loss Equation}

Erosion from source areas was calculated to estimate the quantities of sediments from mine waste sites that have been transported downwash per storm event. Although the Universal soil loss equation (USLE) was developed to model sheet erosion of sediments from agricultural fields, it can be used for the modeling of rolling waves of sediment as presented by Baver et al. (1972):

$$
A=R K L S
$$

where $\mathrm{A}$ is the mass of sediment lost from a unit area (metric tons per acre), $\mathrm{R}$ is precipitation in $\mathrm{cm}$ after accounting for the average infiltration rate, $\mathrm{K}$ is erodibility of sediment, and LS is the slope length factor. To determine LS (Slope factor) the following equation was used according to Stone (2000):

$$
L S=[0.065+0.0456(\text { slope } \%)]+\left[0.006541(\text { slope } \%)^{2}\right] x\left(50 m 22.1^{-1}\right)^{N N}
$$

where slope length is the length of slope in meters, slope is slope-steepness (\%). According to Stone (2000), NN is 0.5 for slopes $>5 \%, 22.1$ is a factor used for metrics, while other numerical values are empirical constants recommended by Stone (2000). Before using the USLE, the average infiltration rate was determined (Linsley et al., 1967):

$$
W=\frac{P-R}{t_{R}}
$$

where $\mathrm{P}$ is precipitation in $\mathrm{cm}, \mathrm{R}$ is the runoff coefficient, $t_{\mathrm{R}}$ is the duration of a storm event or period, and $\mathrm{W}$ is the average soil infiltration rate for the region in $\mathrm{cm}$ per hour. $\mathrm{P}$ and $t_{R}$ are measured values while $R$ can be calculated by using the following equation by Linsley et al. (1967):

$$
R=K P
$$

where $\mathrm{P}$ is precipitation in $\mathrm{cm}, \mathrm{K}$ is erodibility of sediment defined by Novotny and Chester (1981) for sandy loam as 0.47 (dimensionless). To validate the $\mathrm{K}$ factor recommended by Novotny and Chester (1981), divide $\mathrm{R}$ by the precipitation, the value obtained by this exercise will equal $\mathrm{K}$. 


\subsection{Wash Sediment Sampling and Analysis}

The sediment sampling was designed to assess possible transport of $\mathrm{CN}^{-}$and trace elements downwash from source areas by storm-water runoff. Twelve composite samples were collected in a staggered pattern downwash from source areas up to $6000 \mathrm{~m}$ in each of the three washes. Each composite sample was composed of three sediment samples, collected ( $\leq 5 \mathrm{~cm}$ depth) in a linear fashion across the wash area at the sampling distance locations. In a similar manner samples were also collected at 60,120 , and $180 \mathrm{~m}$ above the source areas for background levels assessment followed by sampling of the source areas and beyond at 50, 100, 200, 400, 1000, 2000,4000 , and $6000 \mathrm{~m}$ downwash from source materials. The location of waste tailings for each sampling starting point is shown in Figure 1.

All sample preparation and analysis was according to USEPA protocols under solid waste manual 846 (SW-846) (USEPA, 1997). Samples were prepared using standard procedures and the $<2 \mathrm{~mm}$ fraction was analyzed for $\mathrm{CN}^{-}$ and trace elements, $\mathrm{Hg}$ and $\mathrm{Pb}$. Analysis for $\mathrm{CN}^{-}$was performed using distillation followed by colorimetric analysis by USEPA method 9010 . Mercury was analyzed by aqua-regia potassium permanganate preparation followed by cold vapor atomic adsorption (CVAA) according to USEPA method 7471. Sediment samples were digested by EPA method 3050, hot aqua-regia, and analyzed for $\mathrm{Pb}$ by inductively coupled plasma - atomic emission spectroscopy (ICP-AES) per EPA 6010. Quality Control (QC) included the collection and analysis of duplicate field samples and USEPA approved certified reference material (CRM). Analytical Standards were required to achieve $\pm 5.0 \%$ recovery of true values with an $\mathrm{R}^{2}$ of 0.995 or greater for acceptability under USEPA guidelines (USEPA, 1986). All analyses met the required QA/QC limits of the methods used.

\section{Results and Discussion}

\subsection{Observed Trends}

The surficial sediments are sandy in texture and contain $<1 \%$ organic carbon (Longwell et al., 1965). The 12 composite sediment samples analyzed from each wash showed generally low levels of $\mathrm{CN}^{-}$and $\mathrm{Hg}$ (Sims, 2011). The local background concentrations of $\mathrm{CN}^{-}$or $\mathrm{Hg}$ were below detection limits as expected as both are anthropogenic inputs in historic mining operations. Lead was detected between 11 and $127 \mathrm{mg} \mathrm{kg}^{-1}$ in the background locations (Table 1).

Cyanide, $\mathrm{Hg}$, and $\mathrm{Pb}$ levels in wash sediments indicate mine tailings have eroded into the wash systems from mine sites. Each wash system exhibited similar levels of $\mathrm{CN}^{-}, \mathrm{Hg}$, and $\mathrm{Pb}$ with an overall decrease in concentration between source areas and $6000 \mathrm{~m}$ downwash (Table 1). Cyanide mean concentrations across the washes ranged between $0.89 \mathrm{mg} \mathrm{kg}^{-1}$ and $1.23 \mathrm{mg} \mathrm{kg}^{-1}$, $\mathrm{Hg}$ mean concentrations ranged between $0.49 \mathrm{mg} \mathrm{kg}^{-1}$ and $0.59 \mathrm{mg} \mathrm{kg}^{-1}$, and $\mathrm{Pb}$ mean concentrations ranged between $72 \mathrm{mg} \mathrm{kg}^{-1}$ and $482 \mathrm{mg} \mathrm{kg}^{-1}$. The highest concentrations of $\mathrm{CN}^{-}$were found in the Carnation wash sediment while Eagle wash had the highest source $\mathrm{CN}^{-}$ at $4.15 \mathrm{mg} \mathrm{kg}^{-1}$; however, it's concentration in Eagle wash sediment was much less than those of the Carnation wash (Table 1).

Table 1. Contaminants eroding into surface sediments in the three washes $\left(\mathrm{mg} \mathrm{kg}^{-1}\right)$

\begin{tabular}{llllllllll}
\hline & \multicolumn{3}{l}{ Carnation } & \multicolumn{3}{l}{ Eagle } & \multicolumn{3}{l}{ Techatticup } \\
\hline Location $^{¥}$ & $\mathrm{CN}^{-}$ & $\mathrm{Hg}$ & $\mathrm{Pb}$ & $\mathrm{CN}^{-}$ & $\mathrm{Hg}$ & $\mathrm{Pb}$ & $\mathrm{CN}^{-}$ & $\mathrm{Hg}$ & $\mathrm{Pb}$ \\
\hline $\mathrm{BG}$ & $<0.01$ & $<0.01$ & $<0.01$ & $<0.01$ & $<0.01$ & $<0.01$ & $<0.01$ & $<0.01$ & 12.7 \\
Source & 2.14 & 1.31 & 120 & 4.15 & 0.85 & 732 & 2.72 & 1.49 & 1420 \\
50 & 1.18 & 0.34 & 107 & 0.57 & 0.45 & 721 & 1.18 & 0.35 & 732 \\
100 & 1.35 & 0.36 & 133 & 0.57 & 0.32 & 592 & 1.36 & 0.36 & 496 \\
200 & 1.35 & 0.40 & 84 & 0.87 & 0.79 & 127 & 0.95 & 0.46 & 564 \\
400 & 1.15 & 0.39 & 81 & 0.61 & 0.78 & 118 & 0.35 & 0.74 & 541 \\
1000 & 1.08 & 0.38 & 74 & 0.51 & 0.61 & 31 & 0.15 & 0.30 & 517 \\
2000 & 0.25 & 0.19 & 78 & 0.14 & 0.48 & 139 & 0.15 & 0.23 & 315 \\
4000 & 1.54 & 0.21 & 57 & 0.12 & 0.85 & 55 & 0.75 & 0.53 & 446 \\
6000 & 0.88 & 0.09 & 53 & 0.08 & 0.61 & 739 & $<0.01$ & $<0.01$ & 178 \\
STDV & 0.51 & 0.34 & 33 & 0.36 & 0.21 & 308 & 0.82 & 0.42 & 158 \\
Mean & 1.23 & 0.49 & 72 & 0.71 & 0.59 & 350 & 0.89 & 0.53 & 482 \\
Max & 2.14 & 1.31 & 133 & 4.15 & 0.85 & 739 & 2.72 & 1.49 & 1420 \\
Min & 0.25 & 0.09 & 53 & 0.08 & 0.32 & 31 & $<0.01$ & $<0.01$ & 178 \\
\hline
\end{tabular}


$\mathrm{BG}=$ background averaged for 3 points up gradient from source materials. Source is mine waste material at Carnation, Eagle or Techatticup, respectively, eroding into wash system. Background concentrations not used in statistical calculations, locations are in meters. $¥$, Locations are in $\mathrm{m}$ from the source area.

Mercury and $\mathrm{Pb}$ showed similar trends to $\mathrm{CN}^{-}$in washes with initially large concentrations in the source areas followed by a decrease along wash systems, except in the Eagle wash where they ( $\mathrm{Pb}$ and $\mathrm{Hg}$ ) increased beyond $4000 \mathrm{~m}$. Other studies have suggested that different trends could be the result of sediment transport moving greater masses of mine waste during storm events (Hayes et al., 2009).

In downwash areas of all three wash systems, $\mathrm{CN}^{-}$was below the USEPA risk based soil - groundwater pathway soil screening level (SSL) of $7.4 \mathrm{mg} \mathrm{kg}^{-1}$, and therefore $\mathrm{CN}^{-}$does not pose an environmental risk. Soil screening levels are USEPA goals set for contaminants in soils around housing, farming, industrial, and mining areas. Results indicate $\mathrm{Hg}$ and $\mathrm{Pb}$ are above soil - groundwater pathway SSL of $0.03 \mathrm{mg} \mathrm{kg}^{-1} \mathrm{Hg}$ and $14 \mathrm{mg} \mathrm{kg}^{-1} \mathrm{~Pb}$. With transport of contaminants $\left(\mathrm{CN}^{-}, \mathrm{Hg}, \mathrm{Pb}\right)$ evident and $\mathrm{HG}$ and $\mathrm{PB}$ are above soil - groundwater SSL, risks to human, plant, and animal health are low due to low sediment moisture and precipitation.

\subsection{Environmental Risk}

The risk to the wider environment is import. Evaluating the current and future transport of contaminated waste must be examined to predict possible impacts. To determine the amount of contaminated wastes eroding into ephemeral washes during a typical storm event, the Universal Soil Loss Equation (Eq.1) was utilized. Infiltration rate of rainfall into soil was calculated to be $0.0017 \mathrm{~cm} / \mathrm{hour}$ (Eq.3) and therefore, not considered significant for the typical 20 minute storm. Other authors have suggested that soil infiltration rates in desert environments are insignificant where precipitation exceeds infiltration rates (Horton, 1940; Huggins \& Monke, 1966; Bras, 1990). For this typical storm event and applying the USLE, approximately 0.826 metric tons of sediments per acre can erode from source areas to the wash systems. Sediment erosion thus would equal 8.3 metric tons, per typical event, at the Carnation and Eagle source areas that are both 10 acres in size, and 41.3 metric tons at the Techatticup which is approximately 50 acres in size.

Taking into account previous study predictions of frequency, one event equal to June 21, 1958 occurred per year would erode 581 metric tons of source tailings from Carnation and Eagle and 2,800 metric tons from the Techatticup since closure. Based on historical storm events, the Carnation and Eagle mines would take 4,200 years whereas the Techatticup would need 5,900 years to completely erode and be transported to Lake Mohave. Current conditions, if unchanged, would pose little, if any, environmental risk to the wider environment. However, according to Barnett et al. (2008) climate change might result in widespread increases in precipitation, perhaps as much as 2 to 10 times the present day average, or, could increase storm intensity or frequency.

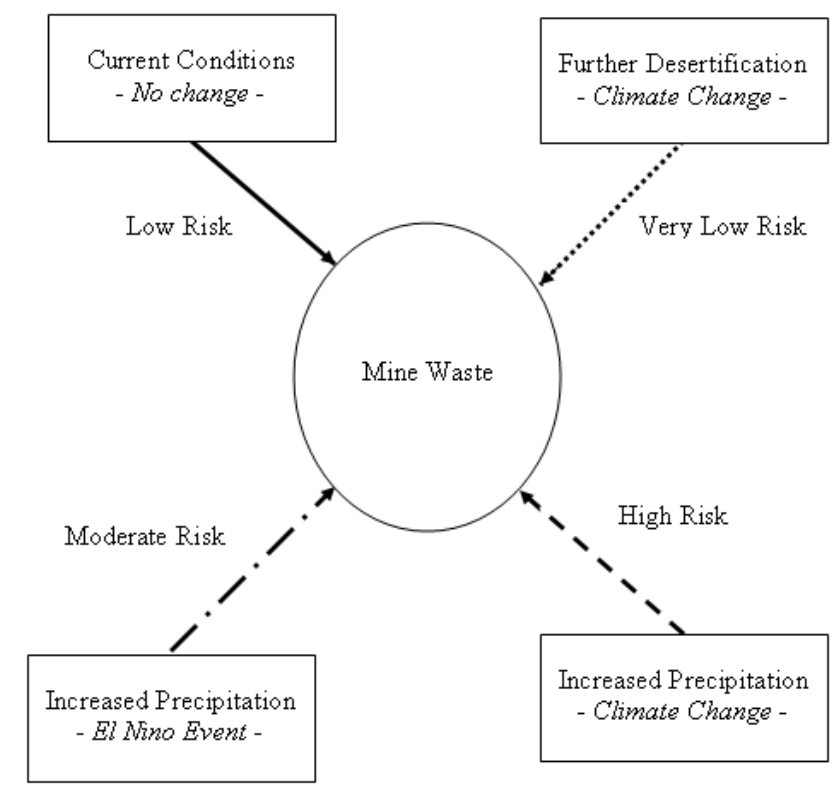

Figure 2. Environmental Conceptual Model representing four possible environmental conditions and their related risks 
Figure 2 depicts possible risk posed by abandoned mining sites to the wider environment. While future risks are difficult to predict, it is possible to evaluate scenarios for total erosion of sediments based on hypothetical conditions. For example, studies indicate that global climate change can either reduce or intensify precipitation as a result of climate change. It is possible for climate change to reduce erosion of mine waste, benefiting the wider environment. Figure 2 shows possible risk of transport mechanisms due to environmental shifts. First, currently conditions present a low risk of transport from source due to recorded precipitation in the area (NWS, 2010). Second, further desertification results in very low risk with the region receiving less precipitation. Third, moderate risk is an increased in precipitation due to seasonality or short term environmental shits from ENSO events. Finally, high risk is a dramatic climate shift resulting in significant precipitation.

\subsection{Erosion Estimates}

An increase in storms would provide favorable conditions for sediments to be transported farther downwash in greater quantities (USDA-SCS, 1977). Of course, these are assumptions and at best may represent worst case scenario for future events. However, according to Boer et al. (1992), ENSO can predictably produce storm events 5 times more frequent than current precipitation. Following their example, erosion of waste tailings is estimated at 41.3 metric tons/yr for Carnation and Eagle and 206.5 metric tons/yr for the Techatticup will be eroded and transported down wash (Figure 3), provided in a highly unlikely situation such an event occur every year. Whilst ENSO is relatively predictable, occurring every 5 to 7 years (Boer et al., 1992), it usually has a 1 year cycle, providing for a slightly higher risk of contaminated sediment exposure to the wider environment. Though ENSO does pose some increased environmental risk for more rapid erosion of contaminated sediments, the return to current conditions reestablishes the stable, low risk environment (Iwashima \& Yamamoto, 1993).

If global climate change increased precipitation in the Nelson area, what change might one see with regards to waste tailings? Barnett et al. (2008) and others suggest that climate change can increase storm frequency $>10$ times current rates in arid environments (Iwashima \& Yamamoto, 1993; Hancock, 2009). Long-term environmental impacts could be increased with climate change according to current predictions (e.g. Serrat-Capdevila et al., 2007; Holmgren et al., 2001; Rodriguez et al., 2005). Furthermore, environmental shifts of El Nino might increase local precipitation in the Mojave Desert, even though it is a short period of time (every seven or so years) that this event typically impacts local weather conditions. According to Bras (1990) natural climate variability on water resources and ecosystems make for difficult predictions of future events. With this in mind, this study used a simplified predictive model based on constant erosion rates over time.

Utilizing the USLE for computation, the erosion rates of source areas for each wash were determined for three rainfall conditions previously discussed: current conditions, ENSO events that occur once every 7 years, and dramatic climate change (Figure 3). Based on the erosion rates for each condition, and associated estimates, of total masses of materials at each wash, complete erosion of each source mass was projected. Using the storm event of June 21, 1958 as previously described, complete erosion of the three source areas under current conditions may require 4,000 -6,000 years. The current conditions combined with ENSO every 7 years, complete erosion of the three source areas may require 3,000-4,000 years. Using the storm event of June 21, 1958 to evaluate possible climate change, complete erosion of the three source areas is greatly accelerated. Such a frequency increase could produce erosion at the Carnation and Eagle washes of 99.1 metric tons/yr and 495.6 metric tons/yr at the Techatticup, and complete erosion of the three source areas requires about 400-500 years, based on USLE approximations. Because ENSO and climate change can possibly increase erosion of sediments, contaminated tailings would enter the washes at greater rates, increasing potential exposures and risks to human health and the environment.

Although current climatic conditions lack chemical processes that would elevate the status of $\mathrm{Hg}, \mathrm{Pb}$, or even $\mathrm{CN}^{-}$to greater environmental risks, an increase in erosion of tailings can provide for the mechanism by which contaminants become significant risks. For example, studies have shown that where moisture is available (e.g. soils, lakes, ponds) that geochemistry conducive to the methylation of $\mathrm{Hg}$ might develop, resulting in an anaerobic setting for the reduction to methyl-mercury $\left(\mathrm{CH}_{3} \mathrm{Hg}^{+}\right)$(Bonzongo et al., 1996; Mastrine et al., 1999). Greater amounts of sediment containing $\mathrm{Hg}$ transported to Lake Mohave, or in ponds created by greater rainfall, could achieve these favorable conditions. 


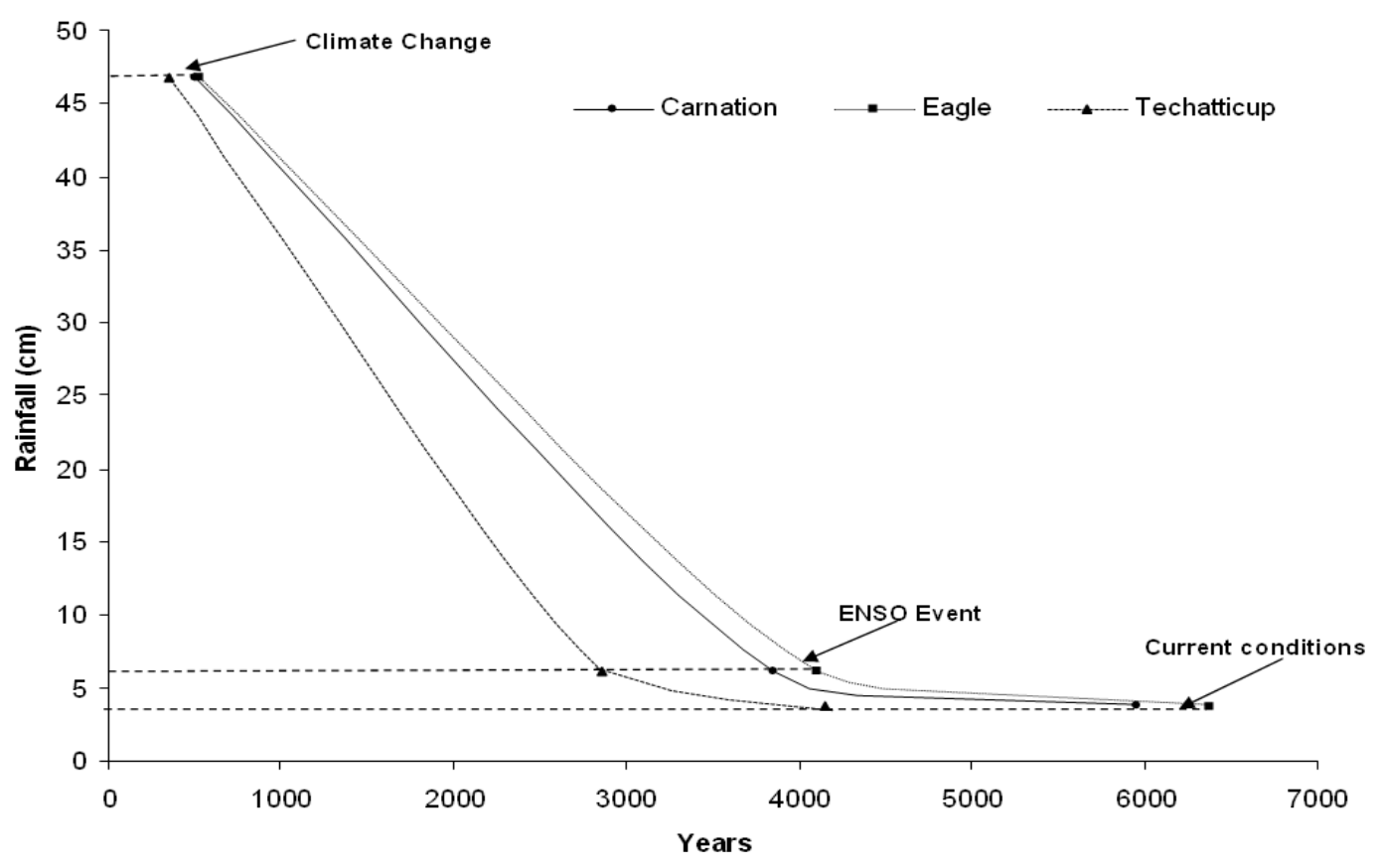

Figure 3. Estimated source erosion rates for Current, ENSO and Climate Change. Figure depicts changing conditions over time with respect to current, ENSO and dramatic climate change with years as a function of erosion timeline due to rainfall

\section{Conclusions}

Abandoned mine sites located in hyperarid regions under present day climatic conditions are presumed to pose no significant threat to the wider environment. Data show this to be generally true with current environmental conditions, but not necessarily the case for potential future climate changes. Currently, environmental conditions pose low risks to human health and the environment in areas downwash from source areas of the Carnation, Eagle, or Techatticup washes. If further desertification occurs, risk to downwash environments would be reduced even more. However, increases in precipitation events by ENSO or climate change could increase the risk to the wider environment downwash from sources areas, e.g., Lake Mohave.

Currently, there are more than 300,000 abandoned mining sites located in Southern Nevada and countless more globally in similar dry environments. Many of these sites are little more than adits and shafts; however, a small percentage could be similar to those in Nelson where large amounts of processed tailings and mill waste were produced and openly disposed. Based on estimates of increased erosion rates of source materials with increasing precipitation frequencies and intensities caused by ENSO or climate change could result in greater risks to human health and the environment. Sites located elsewhere that are significantly more contaminated could be at an even greater risk for waste mobilization into the wider environment. If climate changes impact the local environments with increases in precipitation and intensification and frequency of storm events, pathways for contaminants to enter the wider environment might ultimately impact the food chain. The possible risks of impacting the wider environment in Nelson, Nevada provide examples for similar sites located in arid regions of the western United States as well as abroad.

\section{References}

Álvarez-Ayuso, E., García-Sánchez, A., Querol, X., \& Moyano, A. (2008). Trace element mobility in soils seven years after the Aznalcóllar mine spill. Chemosphere, 73(8), 1240-1246.

Barnett, T. P., Pierce, D. W., Hidalgo, H. G., Bonfils, C.,Santer, B. D., Das, T., ... Dettinger M. D. (2008). Human-induced changes in the hydrology of the western United States. Science, 319, 1080-1083. http://dx.doi.org/10.1126/science. 1152538

Baver, L. D., Gardner, W. H., \& Gardner, W. R. (1972). Soil Physics. New York: John Wiley \& Sons, Inc.

Boer, G. J., Farlane, N., \& Lazare, M. (1992). Greenhouse gas-induced climate change simulated with the CCC 


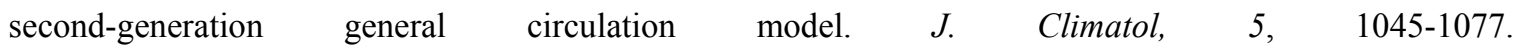
http://dx.doi.org/10.1175/1520-0442(1992)005\%3C1045:GGCCSW\%3E2.0.CO;2

Bonzongo, J. C., Heim, K. J., Warwick, J. J., \& Lyons, W. B. (1996). Mercury levels in surface waters of the Carson River-Lahontan reservoir system, Nevada: Influence of historic mining activities. Environmental Pollution, 92(2), 193-201. http://dx.doi.org/10.1016/0269-7491(95)00102-6

Bras, R. L. (1990). Hydrology: An introduction to hydrologic science. New York: Addison-Wesley Publishing Company.

Bureau of Reclamation [BOR]. (1995). Preliminary assessments-Henderson Lead Site, Clark County, Nevada-EPA ID No NV5141190608-Draft, Boulder City, Nevada.

Dillon, M., \& Rundell, P. (1990). The botanical response of the Atacama and Peruvian desert floras to the 1982-83 El Nino event. Oceanography Series, $52, \quad$ 487-504. http://dx.doi.org/10.1016/S0422-9894(08)70047-3

Dore, M. H. I. (2005). Climate change and changes in global precipitation patterns: What do we know? Environment International, 31, 1167-1181. http://dx.doi.org/10.1016/j.envint.2005.03.004

Giannini, A., Biasutti, M., \& Verstraete, M. (2008). A climate model-based review of drought in the Sahel: Desertification, the re-greening and climate change. Global and Planetary Change, 64, 119-128. http://dx.doi.org/10.1016/j.gloplacha.2008.05.004

Gillespie I. G., \& Loik, M. E. (2004). Pulse events in Great Basin Desert shrublands: physiological responses of Artemisia tridentata and Purshia tridentata seedlings to increased summer precipitation. J. Arid Env., 59(1), 41-5. http://dx.doi.org/10.1016/j.jaridenv.2004.01.007

Giorgi, F., \& Lionello, P. (2008). Climate change projections for the Mediterranean region. Global and Planetary Change, 63, 90-104. http://dx.doi.org/10.1016/j.gloplacha.2007.09.005

Greene, James M. (1975). Life in Nelson Township, Eldorado Canyon, and Boulder City, Unpublished Masters Thesis, History Department, University of Nevada, Las Vegas.

Hancock, G. R. (2009). A catchment scale assessment of increased rainfall and storm intensity on erosion and sediment transport for Northern Australia. Geoderma, 152, 350-360. http://dx.doi.org/10.1016/j.geoderma.2009.07.003

Hansen, S. M. (1962). The Geology of the Eldorado Mining District, Clark County, Nevada. A dissertation in the Geology Department, University of Missouri.

Hayes, S., White, S., Thomas, T., Thompson, L., Maier R., \& Chorover, J. (2009). Changes in lead and zinc lability during weathering-induced acidification of desert mine tailings: Coupling chemical and micro-scale analses. App. Geochemistry, 24(12), 2234-2245. http://dx.doi.org/10.1016/j.apgeochem.2009.09.010

Hereford, R., Webb, R. H., \& Longpré, C. I. (2006). Precipitation history and ecosystem response to multidecadal precipitation variability in the Mojave Desert region, 1893-2001. Journal of Arid Environments, 67, 13-34. http://dx.doi.org/10.1016/j.jaridenv.2006.09.019

Holmgren, M., Scheffer, M., Ezcurra, E., Gutiérrez, J. R., \& Mohren, J. (2001). El Niño effects on the dynamics of terrestrial ecosystems. Trends in Ecology \& Evolution, 16(2), 89-94. http://dx.doi.org/10.1016/S0169-5347(00)02052-8

Horton, R. E. (1940). An approach towards a physical interpretation on infiltration capacity. Soil Sci. Soc Am. J., $5,399-417$.

Huggins, L. F., \& Monke, E. J. (1966). The mathematical simulation of hydrology in small watersheds. Lafayette, Ind.: Purdue University Water Resources Center. Technical report no. 1.

Hughes, M. K., \& Diaz, H. F. (2008). Climate variability and change in the drylands of Western North America. Global and Planetary Change, 64, 111-118. http://dx.doi.org/10.1016/j.gloplacha.2008.07.005

Iwashima, T., \& Yamamoto, R. A. (1993). A statistical analysis of the extreme events: long-term trend of heavy daily precipitation. J. Meteorol. Soc. Jpn., 71, 637-640.

Jamieson, H., Robinson, C., Alpers, C., McCleskey, R., Nordstrom, D., \& Peterson, R. (2005). Major and trace element composition of copiapite-group minerals and coexisting water from the Richmond mine, Iron Mountain, California. Chem. Geo., 215, 387-405. http://dx.doi.org/10.1016/j.chemgeo.2004.10.001

Las Vegas Review Journal (LVRJ). (2011). Accessed on March 18, 2011. Reteieved from http://www.lvrj.com/ 
Linsley, R. K., Franzini, J. B., Freyberg, D. L., \& Tchobanoglous, G. (1992). McGraw-Hill Series in Water Resources and Environmental Engineering. New York: McGraw-Hill, Inc.

Longwell, C. R., Pampeyan, E. H. Bowyer, Ben, \& Roberts, R. J. (1965). Geology and Minerals Deposits of Clark County, Nevada. Nevada: A. Carlisle, Reno.

Mastrine, J. A., Jean-Claude J. Bonzongo, \& Berry Lyons, W. (1999). Mercury concentrations in surface waters from fluvial systems draining historical precious metals mining areas in Southeastern U. S. A. Applied Geochemistry, 14(2), pp. 147-158. http://dx.doi.org/10.1016/S0883-2927(98)00043-2

Meza-Figueroa, D., Maier, R. M., de la O-Villanueva, M., Gónez-Alvarez, A., Moreno-Zazueta, A., Rivera, J., ... Palafox-Reyes, J. (2009). The Impact of unconfined mine tailings in residential areas from a mining town in a semi-arid environment: Nacozari, Sonora, Mexico. Chemosphere, 77, 140-147. http://dx.doi.org/10.1016/j.chemosphere.2009.04.068

Nation Weather Service, accessed October 2. (2010). Retrieved from http://www.wunderground.com/US/NV/Nelson.htm

Navarro, M. C., Pérez-Sirvent, C., Martínez-Sánchez, M. J., Vidal, J., Tovar, P. J., \& Bech, J. (2008). Abandoned mine sites as a source of contamination by heavy metals: A case study in a semi-arid zone. Journal of Geochemical Exploration, 96, 183-193. http://dx.doi.org/10.1016/j.gexplo.2007.04.011

Novotny, V., \& Chesters, G. (1981). Handbook of Nonpoint Pollution. New York: Van Nostrand Reinhold.

Rodríguez R., Mabres, A., Luckman, B., Evans, M., Masiokas, M., \& Ektvedt, T. (2005). "El Niño" events recorded in dry-forest species of the lowlands of northwest Peru. Dendrochronologia, 22(3), 181-186. http://dx.doi.org/10.1016/j.dendro.2005.05.002

Serrat-Capdevila, A., Valdés, J. B., Pérez, J. G., Baird, K., Mata, L. J., \& Maddock III, T. (2007). Modeling climate change impacts - and uncertainty - on the hydrology of a riparian system: The San Pedro Basin (Arizona/Sonora). Journal of Hydrology, 347, 48-66. http://dx.doi.org/10.1016/j.jhydrol.2007.08.028

Sims, D. B. (2010). Contamination mobilization from anthropogenic influencesin the Techatticup wash, Nelsom, NV (USA). Soil and Sediment Contamination, 19(5), 515-530. http://dx.doi.org/10.1080/15320383.2010.486051

Sims, D. B. (2011). Fate of Contaminants at an Abandoned Mining site in an Arid Environment. Unpublished dissertation in environmental science. Kingston University, London.

Slowey A. J., Rytube, J. J., Hothem, R. L., \& May, J. T. (2007). Mercury at the Oat Hill Extension Mine and James Creek, Napa County, California; tailings, sediment, water, and biota, 2003-2004. USGS report: OF 2007-1132, Vol. 60 .

Stone, R. P. (2000). Engineer, Soil Management/OMAFRA; Don Hilborn - Engineer, Byproduct Management/OMAFRA accessed on January 15, 2011. Retrieved from http://www.omafra.gov.on.ca/english/engineer/facts/00-001.htm\#tab3b

United States Department of Agriculture- Soil Conservation Service [USDA-SCS]. (1977). Las Vegas Wash and Tributaries, Clark County, Nevada. Special Report: History of Flooding, Clark County, Nevada 1905-1975.

USEPA. (1986). SW-846, Test Methods for Evaluating Solids and Wastes - Physical/Chemical Methods, CD-Rom. U.S. Environmental Protection Agency.

USEPA. (1997). SW-846, Test Methods for Evaluating Solids and Wastes - Physical/Chemical Methods, U.S. Environmental Protection Agency. December, CD-Rom. 